こ独社とににて論う改

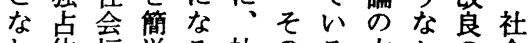

わ体福単る社のる古加の会

れが祉にの会後よ典で意福

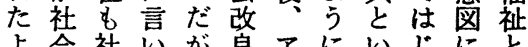

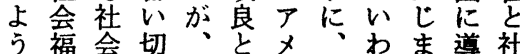

で祉改るしいリーれつか会

あの良わかっ力つるたれ学 る彼、とけした社の $\mathbf{M}$ とたと

ら袂にこ政会社・ み社の

に別はれ治学会りて会関

としいは的は福ッよ調釈

こたが社実科禈チい查は

てのな社泰科調モでで查ンあ社ア

一あよ福的化論ドろ会メ

定つ亏祉な坒少のう問り

のてでと運客もっ。題力

効、あ社動觀い社た。社

捅こる。会と华う会と都会

み袂むと袂のき断ば問が

と別しの別不它々題今

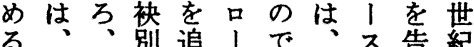

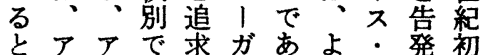

とメメをすンっくワ守頭

むりリあるのたし、るに

に力カつよ\&。らクと社

おののたうと白理い会

く的社年福れれにをたし、本代あ

てな会代祉る社な介と、のでとつ は性福にとよ会っしいだ支あにま な格祉な社う福たてうか配っうり らははる会な祉ととのらのたゔ、 な独こと改一の考はでと大のいア い占これ、良九方えちはい網だたメ で資机独運世にらがなっをが時り あ本古動紀つれついて加、期力 ろの較資型いるた。社けこ洼社

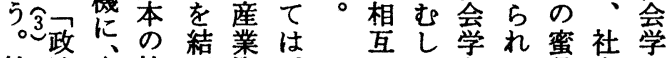

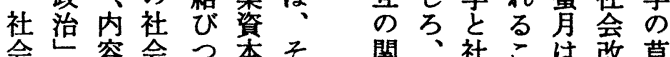
改に容会つ本そ 闇社こは改草

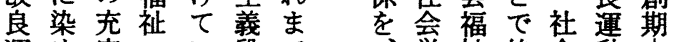
運め実へい段で、学禈終会動

動ぬはのた階の

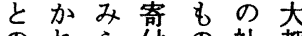
の れら 付 の 社 都 絶たれはで会市 緣もた目あ問の

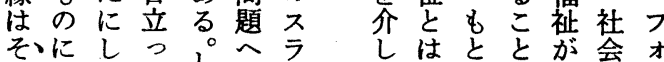

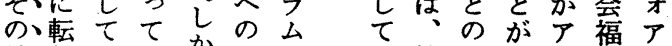
結、化\&子加対問 と社までメ禈の 果し、えし策題り会まきり告 にたそて二がに結改でる力蜜代 ほとのく九、代字良存。独月

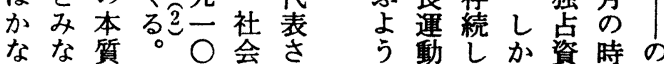

独とのう学?

占社関たと社ビ 资会㐿と社会 本福唯み会学グ を祉、る福・・ 介ともこ祉社 フ 是 
消たはし展学のの事しはたて的こカしか 関ののら 去か、た開この間独情か独。独なのにてっ他心私階な 守の社社さう独が立でも占そ立過過お高た方が物級か るよ会会れし立いはあこ資し化程程けく。化的っ こう福学るてはくそっの本て生にはる評そ社こを私た とに祉が。一必ぶのた独の社るすす、価の会な、物宁 でみが基つ九然ん本の立強会方ぎあ、社学わ化

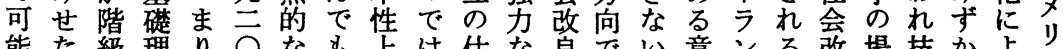

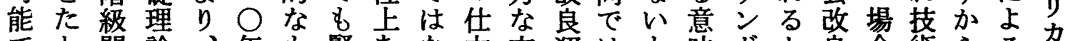
でと関論、年も繁あな方支運はも味ドト良合茂らるか

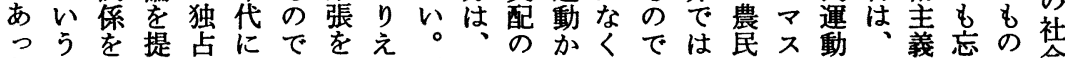

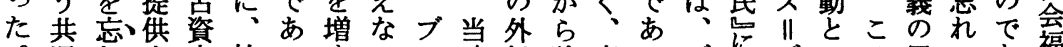
。通れ村本社る守いル時縁独变るブにズのの展ひあ福 社項よるに会。のの沙のに立革。ル求ナ絶よ開とつ禈

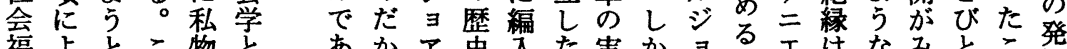

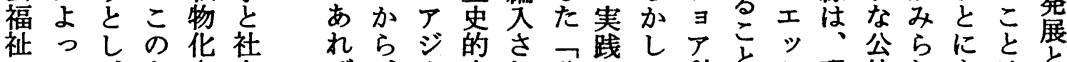
$\sigma \tau 、 よ さ$ 会 技い社う腷 術る会なた祉 化。学関社と

はとが係会の \&階㚙福新

社に級可祉し 会階関能に心 心䌅 倸で相 理的をあ独互 学観 超つ立関 、点越た化倸 文をしのし が

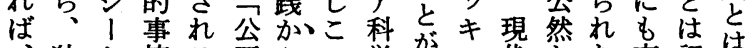
独か情る平らの学架只代たた忘記は 社占ら加こ中独独のでの社るとれ憶独 会資のらと正立立專るっ会私いさ点 改本独すにな化华門るョ学物つせ值資 良立るは站るは化でリの化てるい本 運社とたほ科す充独は壬はよたすに 動会しま加学る变独はッニまいめるよ か改下たなはも革立あパュだでに。る ら良のまら客のの化るとメみあ技そ社

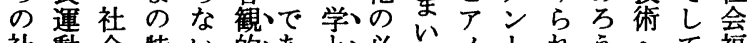

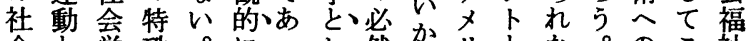
会と学殊。につし、然吕りとな。のこ祉

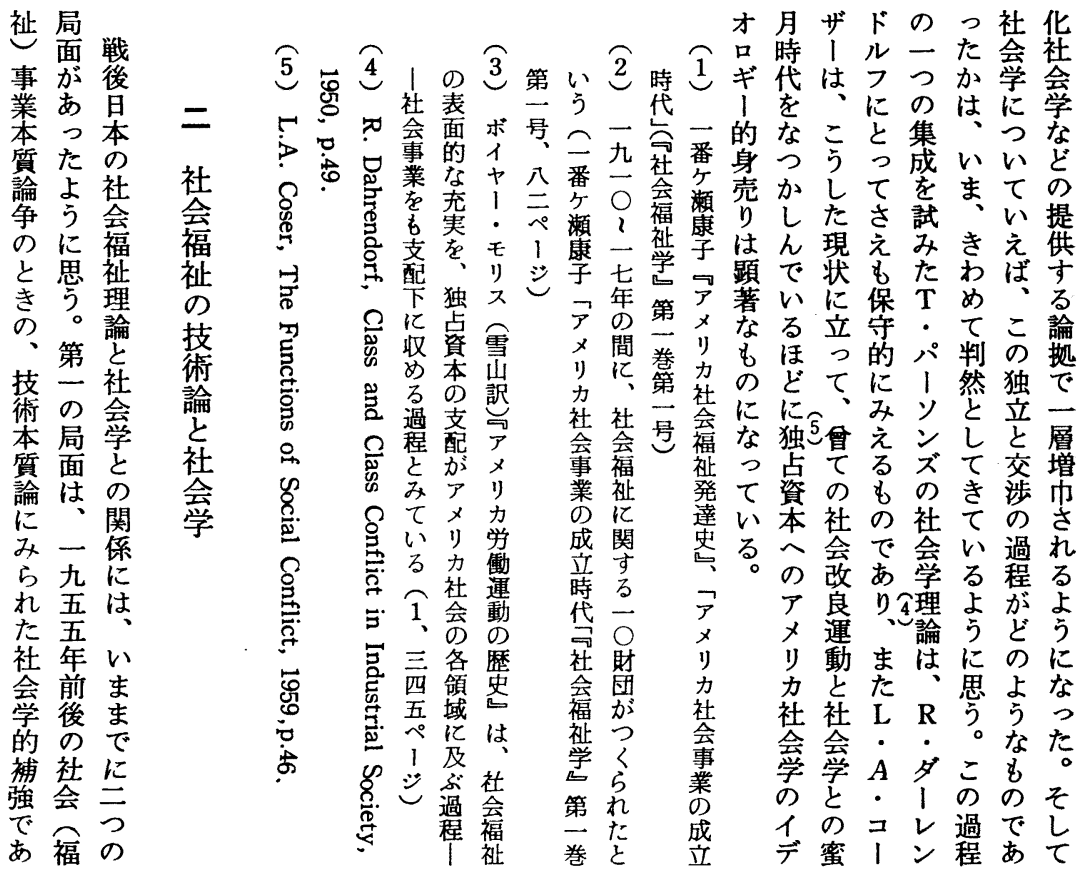


う員恵闘公ほ保も果関たい的をかか級てた面たり 具の思い労と護無たすとた戦事示なら的第特ので六等

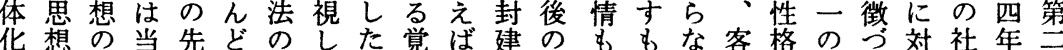
さ闘指然導無よてが書—的つ反のか観の局けし会頃の れ争摘社的疵 うは、然な民映でっ的解面る、学か局 るでと会なのにな戦や四救主しあたに明でこ第はら面 かあ態福闘ま制ら前一五貧化てっ。はにのと先なのは とっ度祉いま度なか九年思しいたそ独求社がのおて二 いた変従でのといら四十想過た。机占め会で局禁社九 うわ革事こ天し。の七三の程。しは資よ福き面欲会六 課けを者の皇てつ民年月惊少本ら祉るで的開○ 題だ迫に官制定ま間の十近 をがるも僚官着り社つ主代社 も、こ影組 僚于救会ワ日化会 当そと響織組る貧事ン付福 然れにしを織が思業デのと祉 内がなた摇で、想のル Gしの 包社るのりあこの一報・て分 し 会。で動るれつ部告 $\mathrm{H}$ 焦野 て福こあか。を近に書・点で い祉のっす戦実代あ化 $\mathrm{Q}$ 今 るのコてわ後施化つなにけ 。領民うけ速方ただよら戦 こ域主おで民営は近もるれ前 ので花上あ主す、代二宁た。 課実亡上る花る二的定社。戦 題務は思がしも方求の会こ中 が的、想、はので貧役救れを

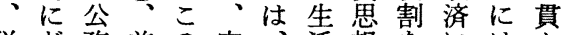
、メょす技 社リるる術 会 力 社 社 本 福か会会 質 祉 5 福 科 論 のの祉学は 技帝の的 術 国 私 観 社 論主物点会 に義化と福 は的の対祉 日な理峙の 本輸論 し 本 独出的た質 自品告の皇でそ 歴受にあの
ᄂアにと市 従ど務慈の官、活想をにはぬ史容ほる階しい局っ

はな発年 政社論以 策会以降 科問への 学題の高 之研社度 し究会経 ての学済 のポの 成 登 | 療長 場 ズ着の をがで破 試主あ産 み調るが たを。明 もな第白 のし一に とてのな

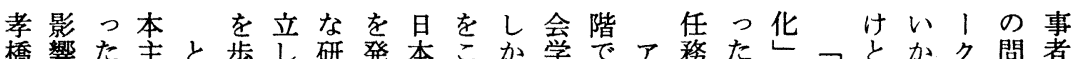
正亡。義もんて究揮にえし、はメかが過近めえに題は 二し危のにだフのしおてま小積りら、程代らる置とク なて機危つ。科成てけ両だ集極カのアで化れと換しラ

ぞあの機民

にら深の主

よわさ樑花

つれはさ先

$\tau \tau$ て過

二き社反程

連会映加

のい福しら

有た祉て独

力。の、立

な大領両立

社河 域 者た

会内でが 社

事一は直会

業男、接 福

論、社に祉

が風会結と

展早政び社

開八策つ会

さ士論く学

れ二のとと

た近重いは

の藤圧

が藤と姿 日

そ文強范本

れ三以と資
学果各る者、団的か態メの亡た

化も分ア唯そ論なら度り福 $\|$ のこるだエ 大野入緊机な役流・力祉只での技けン を量にリ密はど割入処社制民あ場術倭卜 追に”カに全がをし遇会度主る合論小に 求紹侵社癒般救果たの福の化。にへ化ど 寸仝入会着的貧た社独祉内比 るさ”学守な思し会立理実が とれすむる想た学华論を歴 い、る、に民のかむ川の更 うこよ経は主つの技流民的 アれう験至花近よ当術入主二 メ女に科占代 弓初主と化段 リまな学な過化で義と階 力たるとか程沈近化もすと にプいっのにる代がにるし み民社うたな基。化進、とて ら主会名とか礎家华戦いあ 机华問のみでゔ族川よ後うつ

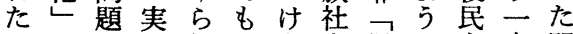
ののの証れっを会民に主定間 と課実主るた与学主な化のは 同題証義。相え、花るの任 じか主のや互た農し。歴務 過ら義本が関が符の 史は民 程独的領て係、社段的あ主
はのさう

、ル対

戦 $1 て す$

後トいべ

のがつき

局開た か

民台と

主れこい

华たろっ

が叒にた

る社な

近こ会る

代と福態

化 が 祉度

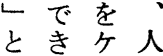

ときるケ ケ間

$\tau \circ$ ○関

受いワ俰 


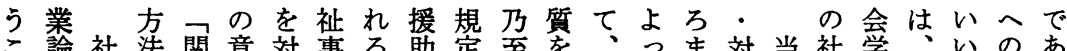

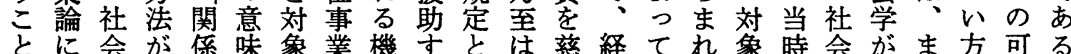
は対福社至はとを能るし外善済、る論のっ有ずを能。 立祉会集事規、ともて側事か社の・木福力もし性た 社すの福団実定貧しの生か業ら会だ技田祉なってのと 会る技祉上寺困てと活らやみ福が術徹し理てい濃え 政の術事が消る者技い維の社る祉、論郎事論、たいば 策だ論業社隇こだ術い持本会こ事とにの業提こ。跌祢 ががとの会しとけ主、困質政と業く分整本供のし会中

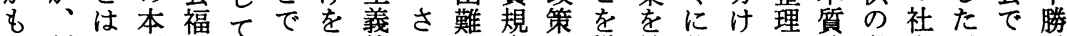
つ制何質祉、汶対的らの定と批補後らに論学会がは男 て度でと事客ほ象規に解との判充者れよ争と政つ社は いをあさ業観社と定、消いかす的はるれでし策て会

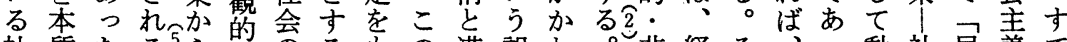

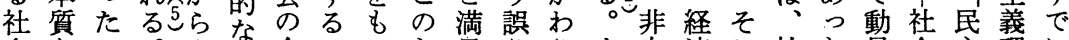
会との。み階全ののた足りりま本済し社た員会主理に のみかた級成はしめなをでた質かて会とさ事化論早

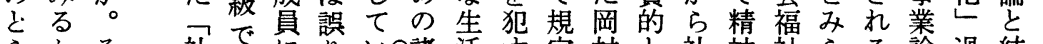
らかそ社でにりい諸活守定村と社神祉らる論過結 え方れ会は及でる制をもし重兵論事れ。と程合社 方法は㝐なほ冖。度営のよ湢と業るこ対吕し会

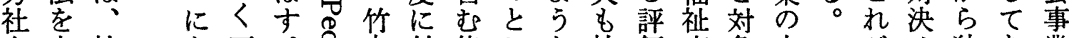
会本社な要。导内付能しと社価事象本がせ独あ業 問質会り求し高愛加力、会が業論質一和立ら理 題と政、穴たを的を内る福な委の論九ばしわ論 のみ策欲欲が高すにも在の祉りみ克は五なたれも

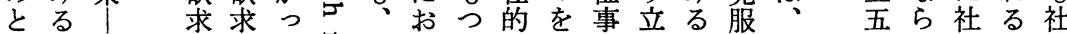

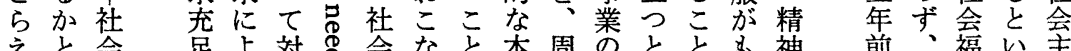

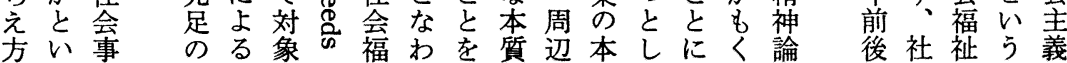

社がめおとにに社つ像るとしこかくて理すみとアへ 会こ承る跓は社み会コにと社かのわみい論るるみメの 理れ認。る福会と政ミない会し労るとる。こ形てリ対 論らさし主祉福め策ユつう的そ衝生め。社と式、力案 ののれか体制祉らか二て考国の生産てし会を主し社を 三試てし的度実れらテいえ家政活政はか問社義た会提 ついこ側を現てみイるがと策と策いし題会的が学出 なはるこ面整のいたしのみに主社とるい理福なっのし が、のにの備手るつがでら分体会し。ず論祉もてそた らマをも調寸段と社援あれけが生社たれをのの社れも をルみ整るとい会角つるら、活会とに唯本で会での みクる社些こしわ会さて。れ単と事えし二質あ問あな と不会ととてなとれ、っる—は業ばてのとっ題っの

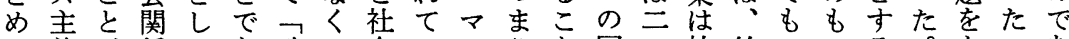
る義が倸てあ政て会いッりと国つ社竹このる。すのあ

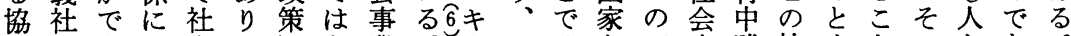
調会き抎会至な業。门こそな生勝社すとのとあ。 的科るけ政社とら社バのれの分活男会るもた人りそ な学。る策会つなら会、三ぞにでには理かでめま、の 観の主|福社いみののうれ社きつ、論どきにた社特 点社体社祉会。た二マはに会るい社、うるこは会異 で会的会学福まつつア、対的領て会社か。そ人をな あ理側事し祉た社のソ-応総域の政会はもをと人社 る論面業と学岡会領シつし資の調策衤人っこ環と会 。と地は岁村告域エのて本よ整を題にとの境人理

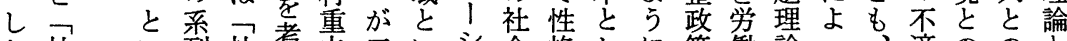

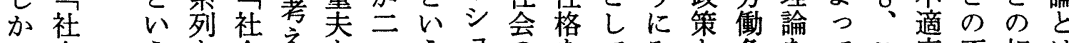

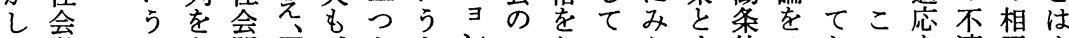
こ学社も関政 なよン三ちのえす件ひちの適互ま

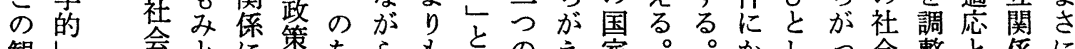
観会とに策ちらをとのた家。加っ会整と倸に 
九クうるる华か的さ社手社てと一こ論会をも主る点 て自と。ㄴむせにもせ会を会いめつとを理公み義もは い体すをた過加否ちら学雄理るるののす論言とにの るをるつと程を定ろれとれ論。か見方みとしぬよで歴 も社なとえの閏しんた社てにそっ方にととてさっあ史 の会かもばな題よ、と会社結しこが重めもいるてる的 の問で仲仲かにう私い福会びてうあ点るにるを破。に 闘題弱村村にしとはわ祉学つ社をるのこ装のえ産私み いの点の優位てし、なとのく会し”あといだすさのれ に元を場二置いて社くは専も福なとるはを汃市みば 期凶露合やゔい会て、角の祉がいの六新らそらるすi 待に呈は忠けのる福はそ地なはらっは社た間のれと社

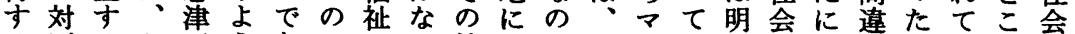
る面るケ王うあでにら技さだこルいか学しいめいろ学 とさこ1枝各るるはおな㣺せがうるで的たなにるで的

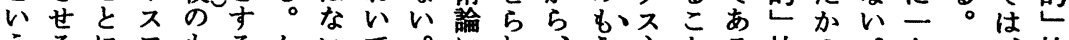
うるにワもるケいて。に机埕とる社の。九こ、社

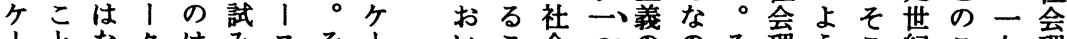
にとなクはみスそ、いこ会いののそ理うこ紀こ九理 スをつの、がワのスてと福の影でれ論なで社と世論

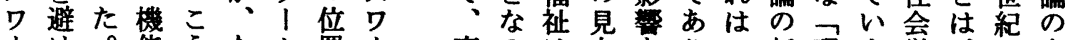

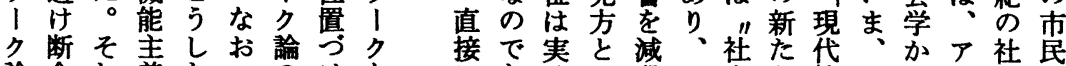
論念れ義た二のけななは祋、会な社、らメ会権 そしはに試部なとど、るマて专ルに復会ルのリ学の のて、活みにか役の排。ルのるクつ権学ク䊉力は復

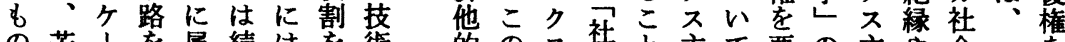

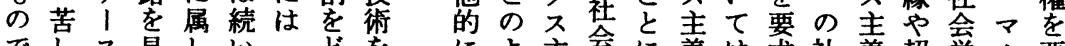

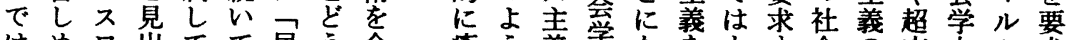

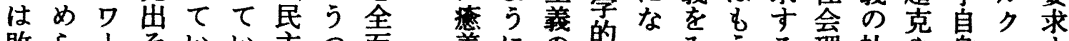

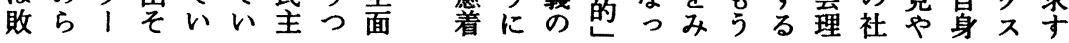

た福

祉 社

し 制 会

加度福

し、の 祉

、運の

や営技

が・術

七実主

そ施義

れの的

はレな

・ヴ 理

特 工解

有ルが

社閴た

会に\&

かの

にぎは

対 5

応れは

するじ

るかめ

理のは

論よ

- 5 単

主にに

張み社

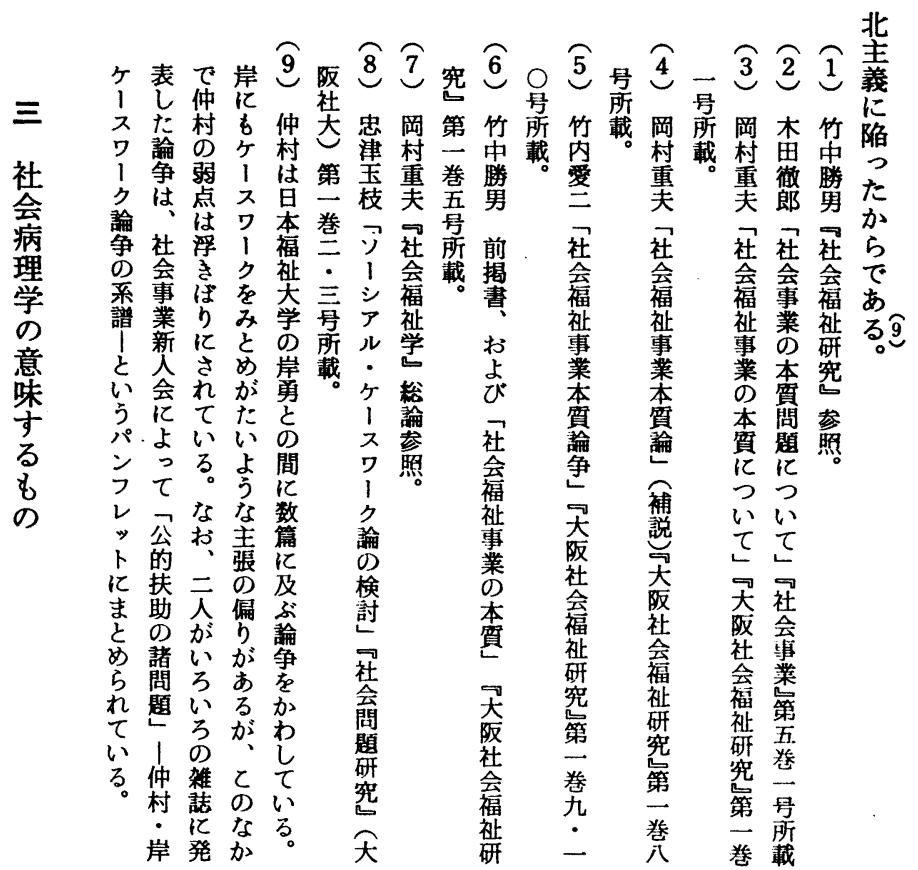


省の社操つし理提的りです病・生の拗よろつ題あ さ相会作まか論と行、はる理土わ発構ないうの社をる 机互問なりしがし為社なこ学开が掘想努まと会社こ る2関題の伝実伏てと会くと年国のは力释会と 。俰研で統は在いし政、はは徳で作技にこる済の福が そが究あ的、したて策社社っ編も業術よのも的承祉明 し弱はるな社て社解を会会社っ、主っこの社認の白 てか、。社会い会釈社問問会社すみ義てとに会を領に こつ抽似会をる理さ会題題偏会でる的まはほ上迫域な のた象た学人の論れ事はの倚病にこ社す的のろにっ 弱こ化この間を。業すい一理二と会ま社なほう応て 点と.と方関み社い安べ側を学九が福す会らかと用い の、概が法俰る会る企偏て面研向で祉は病なにいしっ 克倫含戸代とこ問。倚社ま究が四きとっ理い。ううたた 服理华田社しと題こに会たすあ年る人全き学。い志とを

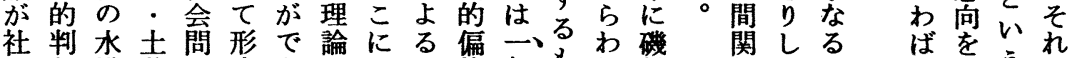

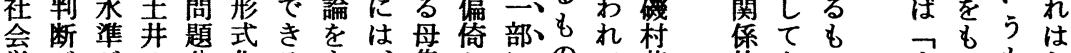
学驾怔分化るも、集加にの英的きの人っもた に介低編野しょ含こ団ら社でい二社ての間たのと ま入か著にて市れと把会ある、会い追関むでえ かしっに接み単込まの握的る。社会る求係のは深 さてたをしる單むで対さ偏。磯会を境的でなビ れいこあてもの新の立机倚そ符病最つ社あくュ

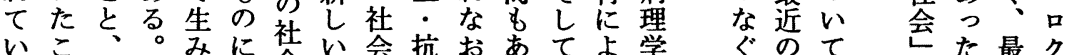

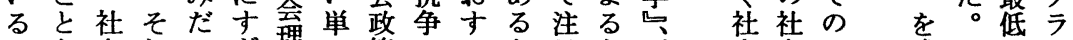
のな会れしぎ理一策へこと自と声会会云成い限シ だと全またな論の論のといに田病病連立う三! かで体で概い社が対にう值社貞理理のさとうの ら新との念。は会前症なのい会兰学学執せ气の問

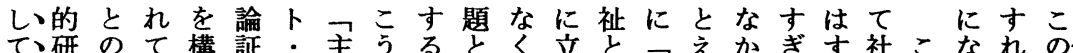

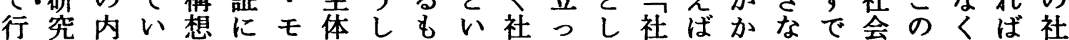
動と実るしあチ的たのう会てて会、らかに政段な、会 䈖には点、る、ア三はの病、統福一社つみ策階る抽学 学三、がそのフプ元客は理方一祉九会たらと留象は 元逆い机だは口的観、的法すと六学。机論、华抽

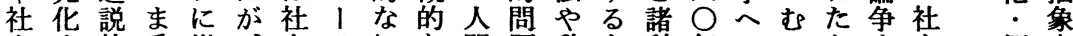
会与的重媒、会于把な間題動も科年のしとす会概度 病るに要乔そ福し握むのに機の学に要ろしる学念の 理こきでさの祉とがの行求にがし鵬請、てとかか化低 学とこあ机際研に社と動め社探と田が社もいららを がでえるて究分会主のる会究心啓意会、うす形了 ああよ。社人のけ福体問と福さう識福な訓る式メ るつう社会間基る祉的題い祉れ論郎化祉お練社化リ 。たが会福行礎根のなとうのる文がさ事大を会に学 。福祉動科拠なもし提つがを动業まま病求社. こ経祉がの学にかのて案統、寄本酸本かた理め会 れ済研制不となをとつが一社せ社酵質な経学て問 を学究度調しつっにかさ的会て会し論あな構きき題 ま的をと整てて制分まれ要福い福て争るい想た研 と社行主現行い度けれて素祉る祉いを意まは形究 め会動体象動る的ら、い事。学つ経味ま、式に 結問科的と科。アれしる祀業こ会たてでに社社ま び題学側し学こプてか。求本このと社牧、会会か つ研で面てをの视社め質で機み会歌本福学せ け究統と社お論、る斿会る論は関ら福的質祉にら ると一に会く文チ机病心争、誌れ祉な的を頼れ 概社す分病このしそを理きの社創る研むな媒るな 念会るけ理とラとし規的で整会利。究の性芥以以 と学こら学のイ、て定問は理福号たのに格し外と 
と会ちるう理と会た告会のア上単けまなにじで五 く病な込こか学お問社発問独メのにででるもての至社 に理おむと。にし題会を題立り要み終の。っい社号会 最学竹こでそ一て理病放研を力請てう社しとる6会に病 初只中をあれ層か論理萧究社でにきて会か実。病寄理 の松和なるはの社理せ学 も原郎の。実と二はる反学社定よい理社的会学たに の・はでまブ践に元、も映が会のうこ学会観病がつは の副、あたル华か的研のしと改歷にとが病点理没社何 な田最る行ジをくに究だたげ良史、で没理を学価会が 加編近。動 $\exists$ 求復か者つもる運的没は価学注を值学期 でっで科アめ権、のたの際動・価な值のぎ単的の待 は福も学社るをマ主のにの政值い的実込にに社さ 祉大会と权ル観でほ擬ら治的。な践んこ具会れ 社社橋 $、$ 学はらク的あか似の的なこ記化での体福て

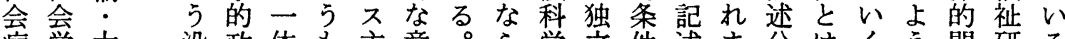
病学大没政体も主意。ら学立件述ま分はくう問研る 理し藪階策何の義図こな的亲の分で析どとに題究の 学な編級㐫で社にういな戦も析にたういつの汃 とどっ的技期あ会かし。学後とはアっいうか記の。 社に社な術街っ問かた何工昌で独メたう方む述貢竹 会も会観・扎題わ負よ1 本応占りとこ向と分献中 福論病点方る。理りいりルでえ資力いとがす析和 祉文理を法ここ論な目もではて本とうに求るにの郎 を学運のとのとくをそあるいの白批なめと終なは を寄占動確によの视り民る亿本判るら始か社 テせ犬に立なう平社っは、主姿デにはの社しで社

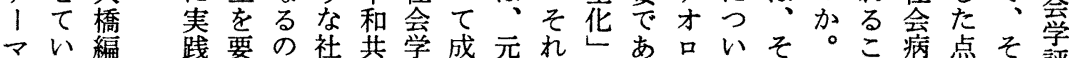

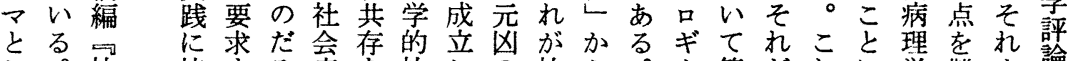

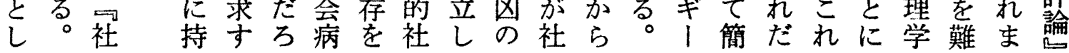

な則にはれ人はわれる竹拾しるは るにも経ら間きたて。中でかのきこ 二対人済变㭆わっい社のあしにわの

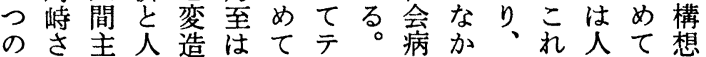
視せ体間守人危 |人理に概は間多に 点らのまる間険、間学は念沜行様あ にれ法たこ関でとはを、操田動なる すて則はと係あな社人こ作に科領意 ぎいと経に市るり会間のでお学域图 い。っとか点現るど外う幻てい広理 もそた社机を代ものをを想、うが解 の机会て頼のの領扱社的す視っで のぞのといりブで域う社なで点てき よれがいるにルあにも福活にで収る うの持うとすジるもの福路みま拾と

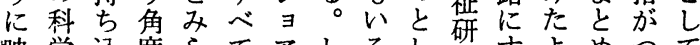
映学込度らてアしるし究すよめつて るの亦机の社かした究ぎうをかむ し側机らる社会し、学こ社き領い名けくな から歴政ら科のの会こ域も名るなず、 ᄂ み史治で学主必諸の搪のあとる。 こと.法る陚性学然はあてうこ会 の、客律。侵みにの性必る実のれ福 各そ観歴経入は乗すは然。のでを祉 領机的史済々、るべつ性しなあ収の 域はなな学しここてくがかいる拾研 に単法どにそのとにらあし収。守究
なきんてつな会て 領、での政つ病い 域 社いつ策な理る を会る8主主が学が 見福。体体りに 出祉こ的ののつこ しはう人側究本こ て、し間明質で いこてのかし的は るっれれ 新問らを側そ 江題の注面れ 克い接文 II な 服社を近し予原り 寸会提に、因の る 病起対他と集 た理しし方な約 め学、て、るが ののこて社 社 み 政対れ労会会ら 治象を働政階れ 的亡方力策級る 行し社の論構

動 て 会側 と造一 理学岕方方 論人的かか体で に間ならか制は 新疎接のわへ し外近接りの従 い名近近で積来 主をととは極の 要お呼しい的社 


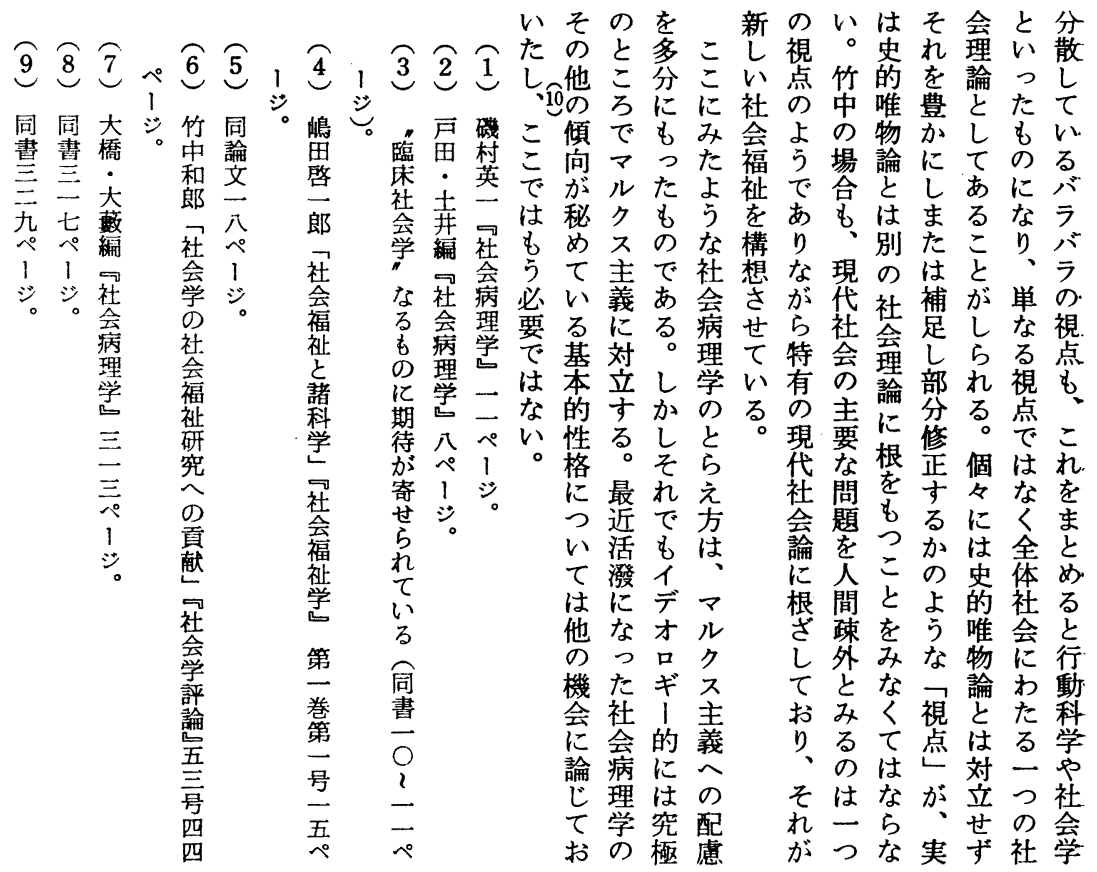

社っまとに策面るのたす岐にのたがと 会このにもとに。領め社る路とよ。何さ高 福亏時皮礼わ独域に会加をっうこらま度 祉に点肉社てた占でそ学と意てなれが成 をなでな会つる資はののい味不間をのま長 政つはこ開社擭本学なう年十接社手なと 策て と発会取と社問かとる分的会を生い 的き独に開とそ会研にこ。に乃福打活う にて占はの発收の開究はろ独な至祉た苦名

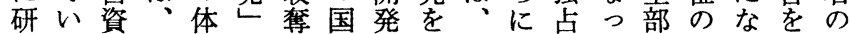
究る本社系をの家論捧す来資て分分くも独 寺。自会的位異は篦でて本き的野てた占 るし身福整置常、がるにいへてなではら資 こかの祉備ゔな高研こ早るのい対みなし本 とし要のがけ強度究と々。公る症るらて主 がい求政要て华成者にと然。療とない義 独うに策請いを長の踏高然そ法、いるす 占まよ論さる破・㷌み度るれと従ま。運 資でっかれわ綻地䞶切成協はい来でそ動 本むて技てけな域をつ長力社うのにれは にな政術いでく開きたく会協社深は 新く策論るあ抵発めむ地 た、論か。る抗とるの域 にこのとしが少い踏も開 従の勝いた、なうみあ発 属勝利 5 が社く国絵る。 さ利を論つ会泰㞎に社成 せの宣点て福施生な社成 れ宣すは祉す活っ会功 るはかいこ究政全い祉の 踏福力会刻 み祉の学な独本 切に仕的問 占社 ると方な題資会 かっで社題楿に そては会とと多 れは独福なそく を重占祉つのの 拒資研て国矛 否な本究き家盾

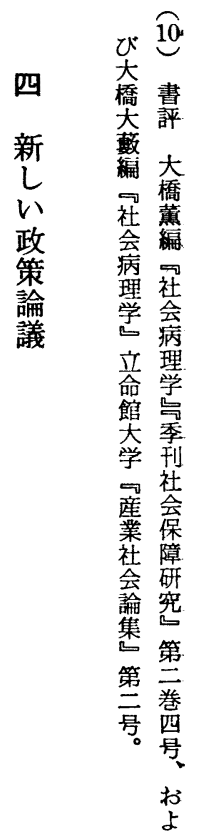




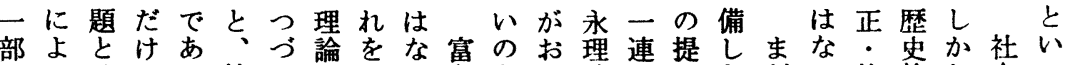

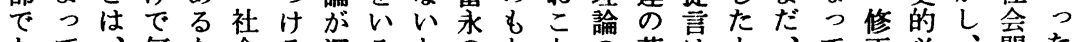
なて、何な会る哚ろとのとなの著はも泟必開た く規経らら体。化いい理にわ役書みの社い守然社発々 な定済理、系社しろう論支れ割・らは会なる的会論勝 るさを論この会発なご構持てに論れな学い祀な開は利 なれ二のれ一が展問く成すいつ文るい的。のつ発 ぞて要名は部経守題当はるるいが。が社と近論高な とい素に当と済るにり点のて社む、会な代は度の いるに值りしたと即前人たでは会し部福つ化地成だ うかしい前てけいしの間け、開ろ分祉て域長が

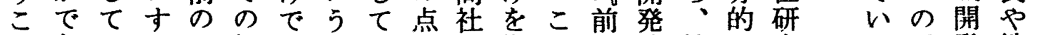
とあいるこ経構のい荟指こ衛論社に究て過発地 がつるもと済成でい訴が摘で惩会地で、程を域 問て社のを体さはかえ経すは誌基福域は地と前開 題、会で別系れなえつ済る地上礎祉開、域し提発 に基とはのとてくるゔたに城やうの発社開てとと な底はなむいいい開可領を会発とし対 る的何いずうる実たてかど発旦の域前開をるた立

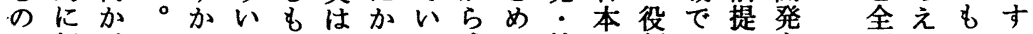
で規。こしいの同らる成る社の割はにを面るのる は定そこい方でしそより。会科㞭なし政的がで面 な守れに言とは地れう立開学果いた策にゆゆあを いるは関葉がな点はなっ発者たが社科

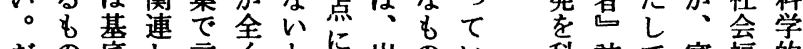
だの底蓮言全とに出のい科誌て富福的 かが的たい同いと発だる $ら$ 社に理かしうど点がす 富会は論え意こまか、の 永の何問た味とりらこで 的でる健学体 な批。面采 装判富ので整

否える。

定に地て

るこ域は

$こ れ$ 開い

と発る。

理にに公ての形もあ殊きよ動ら容が個だだ社と概が

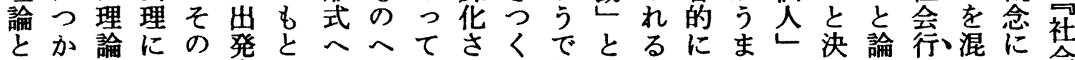

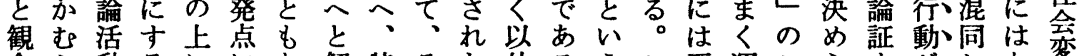
念加動るににと解特そた外るうこ互運こらすがしな得 論観がのいないし殊のむに。共のい占とれる経すり動 的念あでろり社たな間のなこ通場に。なて。済りえ理 社論るはいう会形むににいの項合区経のいあ行かな理

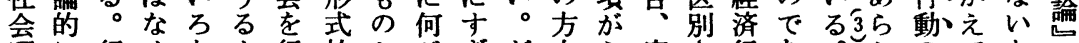
理に行くなむ行社かがきだ向え富さ行あ。㔔のてとで 論つ動、もの動会らあなかでら永れ動る㔚じ基いい、

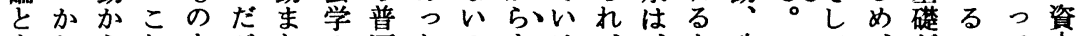

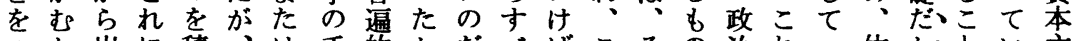
うか出に積、は手的汃たばこその治れて体かとい主 くの発分みこ行法なと社系らをる義 る三すけ上の為をもい出の相をぞが動け会と経物とと

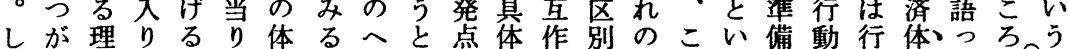
か基論深と前采たと、か的用を特のっし動采ては跑の し本活めなのとけい具らなしこ殊区たてと体はいは仙 第で動科る感みで う体出行あえな別具おは采社る右経

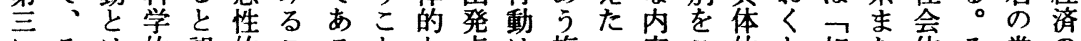
にそは的誤的こるとな点は複一容こ的と相た体そ常の

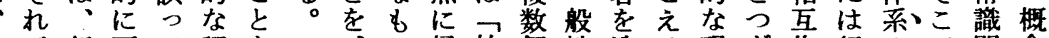
こが行再て認も洲社個性洗る現ぎ作行ので問念

の唯動構く識、 問物壳成る老そ 題論唯す。公れ 索的物るこ理は 回社論これ化二
内只会人と以一実の用為—、題た 容らて行し考落般のよし体特他とか 老抽き動にえ性行うあ系殊方理ら 捨象たしでてとが動にうの㻌論 て的のの゙特行る行め求はこ複こ市は問会 


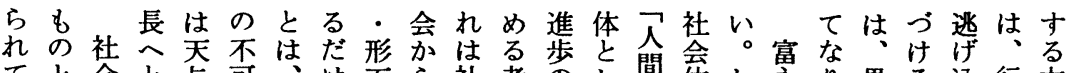
て会と与可、け而ら社考のし間会し䓠り果る込行方 いな開二の知実の上は会え過ての采かの立しやん動法 るる発般論はも学説理が程可はすのし経ってりでをを 社は化技の、の化明論二化社こ変こ済て社方、内経 社とささ術宣さに学での体と会ら動の体い会で行容験 会ここ机進言きな受き息いい外根は上采る萦あ動的批 かで社社紫でにるけな殺つう的榞までとと理るをに判

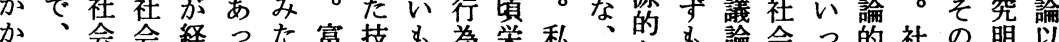
わこ会会経った富技も為采私なも論会っ的社の明以

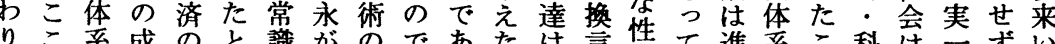
りこ系成のと識がのであたは言情て進采こ科は会ず のにの長成いの好進、りを社守向技んとと学人步にろ なは構が長わ形ん歩社自の会れと術でのは的間も期い い経造社をな式でが会己かのばしのい区そなな哚期ろ 技済変会もく主使社学破を解社年く別机定しめ待試 術開動体たて義っ会で産お明会片歩。はと義にずのみ の発亲らは的て体のでぼを恎亏に社理同たはに覑ら

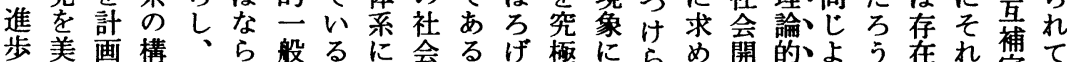
秀美画構、ら般るに会るけ極にらめ開的よう在れ完て

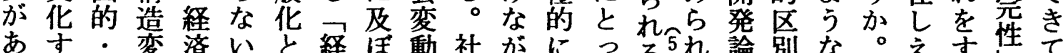

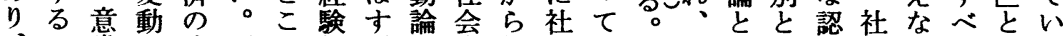
、卜識を成原の的影は変知会与だしのは識会いている こリ的ひ長因客に響、動っ外件加か考にはとのっ。 れッにき杂不観検をこはてのでらもか考す行い基た第

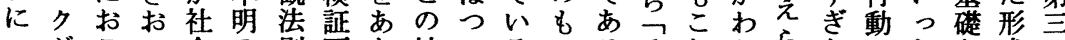
二がここ会の則可と神いるのるそれりらなにたと式の 定秘なすフのま否能う秘に。に技れはでれいよこし化方 のめう各成た定しけ化社こ求術自、はな。っとつに法

きうのはし放こえたし独開住化なぐた行社でなせラ

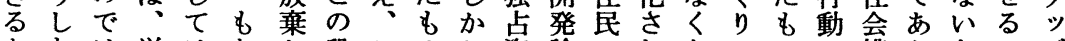
とたは単はとか段このし資論のれなののは構りとのグ いもなな成むら階うでこ本は一たる概で主成、いがを うのいるりと必でしはのに、人行。念あ観体経う経と のを。経立、然はてなソ追経二動そのるのと済。済む でみ独済方社华、後いフ従済人をの形。恣い行経開な あと占行え会ささ者。1守開の経上式こ意う動済発っ ろめ資動な開机らを社スる発努済に主のでとはがでて う本のい発たに形会テ無へ力開、義問どら社先、均 かたにタ。の の技式体 1 理のに発社的題 5 会んこ衡 ○はよイし讃の術論采ケな限さに会操をこ方行すれを 開前るムか美でを理を|ソられ合開作避うに動るは回 発提最・しのあ社的社シフれるわ発をけで屈のに一復 地と大ラそたる会に会ヨィたおせは理るき服下し九打 域し限\%れめ。外下行ンス対そ変、論のるす位て世る でてのグにに も挩をしは 農い取調て 山て、整㟔経 で社奪る経開 も会のと済 発 福計 $、$ 開

社祉画っ発地 会が化た。域 福一で無地 開 祉 体あ 内域 発 は何る容開を 緊が○な発否 の位動はテ立れ华基活でする概も紀経 ᄀ概と理 1 面をさ本動思のこ念々的済 第念し論ケさ秘せ的か考でとなれな行

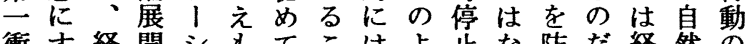
衝す経開シもてこはよ此な防だ経然の 撃る済のヨ影いと役うがくいか済法様 し作を途ンをるで割にお、でら行則式 に業経中しひ年構みこ客い、動とを 寸に済にかそこる造せな観るこが解意 るあ行突みめのかとなわ的。う先さ識 社る動然ら、よらしくれにししんれ的 会。に搜れ徹う、てて、規かてすてに 理そお入な頭な国のは堂定し経るは変 論しきさい徹社民様な々さ経済こな化 急でこ\&と定

のてかれ。尾会・式らめ机済的とらさ 
意こながきてをなるよでるい労なか様けのの済はな

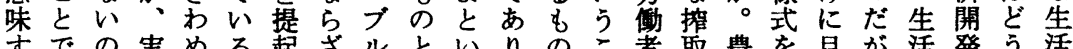
寸での実める起ざといりのこ者取農を目が活発う活 る、ではてかでるジ社う、ととに材漁経を、党をに問 事社あこ素らきをヨ会こ公っでは料民済向こみ地も題 情会るれ朴でるえア福と害近あみにに開けれる域なで を福。がなあのな社祉で地代りずなは発てが目開らあ 祉い政誤るはい会とは域化、かる零にいみ発なれ 最がま策り。学がなのし中らよ細合るえもにいば 後ブよ科の社政そ的結い住す小のうな吕かなちよ問あ のルう学よ会策れ社びか民零労行土せらい合つ題る 、ジやにう在が会つ。はを細㗢動地さでとわてをほ も妇く転に行学、福くこ自の企力様やてあすせ半うど 了、身み動とル社は机分と業を式漁変るれて身き何 と社歴守え体しクがすがでそに流を場え。ばい不うと 会史るて采て不政が社住れは動変老るこ社こ随けむ 苛学的と、とか主策あ会みぞ独华え捨社うごばにらし 酷と現右見みく義科ろ開よれ占すよ会しく理されが な結実の方るも社学う発く行資るうさ開た二解れるた

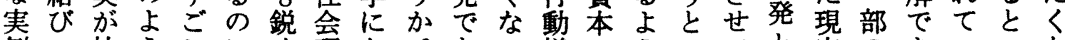
例つ社うしにく理な。ある様のういてと実のきいいな をく会なてと対論ろるる式選にう独はの大るるうう もこ開\& \&と立とうう別行こ占一な資現。形て つと発のいま亡ちと変に動と資体か本実少でい

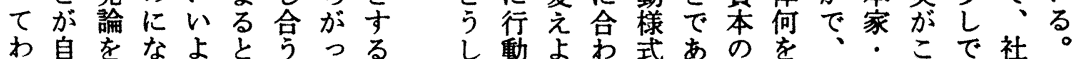
わ自をなよとうっるるし動よわ式あの棤な社経うで社

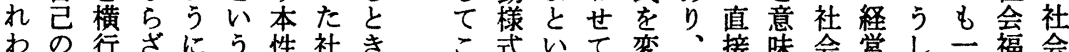
机破さる思のを会はうをう没え中の年行者て般祉福 に局せを教るえるは理こ論う変こ落る高低る動層あ囷は祉

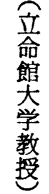

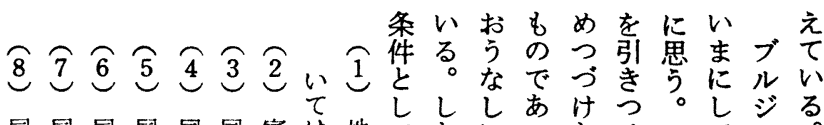
同同同同同富は地てたにったけそてョ。 書書書書書書永司域はが国たもたれみア 歴

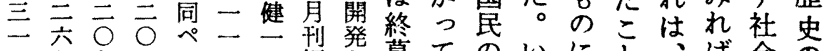
一七九五1六口福と幕て、のいにと、、は会の ペ「ペペシペ社祉社に:生まとはとす学狡 1 八 11 1 1 会会すブ活わつあまき 济ぺ涪湾二福でルとれてつにて社を

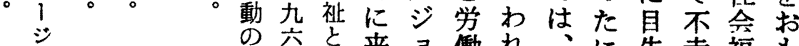

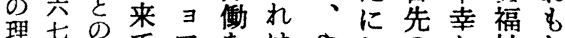
論年閣てアをはやしのな祉わ

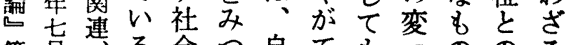
第前る会つ自て\&うののる 二昜つと学め分は、たで蜜を 章でまいとざの南視あ月索 第ふらう社る労げ剣点っはな

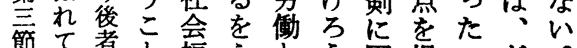

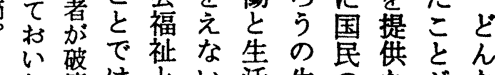
た破はと以活生の福はがな さななよ涯生ど明形 れい不うをを活しかを てだ幸に含閉とてにと いろなさぬ䟫学なろ 過亏蜜れてる湖界つ

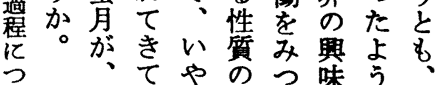


First is a controversy over the real substance of the social (welfare) work around the year of 1955 . Here is the first encounter of the social policy theory and the theory of American Sociology.

Second is an attempt in the field of American sociology at fixing the social problem theory as the basic theory of the social welfare. The "social pathology" is just applied to this. The "social pathology" seems to have attained to the age of maturity, but there still remains a question unsettled concerning the adjustment to the social problem theory of Marxism.

Third is the fact that the demand of the policy science under the monopolistic capitalism has intruded into the field of social welfare. Meeting this demand, American sociology is willing to offer a theory for driving and rationalizing the high economic growth, intensifying the exploitation of people.

None of the theories of American sociology has really protected the health and life of people, and the fact of selling itself into policy science shows nothing but the closing account of this theory.

Honeymoon of American sociology and the social welfare will lead to unhappiness.

\section{The Logic and Technique of Dimensional Analysis of the Social Consciousness}

\section{Akira Aida \\ Niigata University}

This article aims to establish a behavioral scientific method of analysis of the social consciousness. Until behavioral sciences became fully developed, social consciousness had not been an adequate object of scientific investigation, or could only be treated as a subordinate variable to the other variables. In this case the social consciousness was apt to be supposed to be of uni-dimensional structure, because it was examined as a reflection of socio-econmic structure which was abstracted from a unitary point of view. However, for the purpose of problem formulation it is often desirable to give priority to one viewpoint of a unitaristic theory, in order to articulate any particular investigations to the macro-scopic and dynamic (historical) observation.

But when one attempts to examine reality, the social consciousness must be assumed to have a multi-dimensional structure in accordance with actors' 


\title{
Trend of Social Welfare in The Present-day Society
}

\author{
Fumio Miura
}

Institute of Social Security

In this paper I intended to introduce the conception of "community development", grasping its general principles as follows :

(1) Respect and enlightenment of spontaneity, self-help and mutual aid of the inhabitants

(2) Participation of the inhabitants based on their initiative

(3) Integration of the governmental or extraneous aid and the effort of the inhabitants

(4) Many-sided policy from a synthetical view-point

It is needless to mention that each country, developed or underdeveloped, has its own implication of above principles.

As a main issue of this paper I took up a problem of "struggle with poverty" in America, following the growing necessity of the conception of "community develoment" under the "new poverty" of contemporary days. Connected with this tendency, I tried to make it clear why the synthetical view-point is now requested in the field of social welfare, besides the usual efforts to specialization, and thus $I$ intended to point out the fringe of presentday's problem in the field of social welfare.

\section{Post-War Social Welfare Theory and Sociology}

\section{Tadasu Sanada \\ Rithumeikan University}

In this paper I tried to investigate the post-war social welfare theory in Japan, focalizing on three phases. 